\title{
The case system of the Vilamovicean adjective - from description to explanation
}

\author{
Alexander Andrason \\ University of Stellenbosch, Private Bag X1, 7602 Matieland, South Africa \\ Email: andrason@sun.ac.za
}

\begin{abstract}
The present paper offers a detailed description and analysis of the adjectival declensional patterns in the Modern Vilamovicean language. Modern Vilamovicean possesses six declensional patterns, restricted to distinct environments, that, from a morphological perspective, form a continuum ranging from a strong declension (classes 1,2 and 3) to a weak one (class 6), through intermediate mixed paradigms (classes 4 and 5). Nowadays, only the mixed and weak classes are productive and common. If compared with Classical Vilamovicean, the adjectival declension has suffered a process of syncretism and decay, evolving towards a two-case marking: nominative vs. accusative-dative in the masculine singular and nominativeaccusative vs. dative elsewhere. Thus, the adjectival morphological case marking is more effective than in the nominal system (where no case distinction is usually made), but less successful than in the pronominal system (where a three-case distinction predominates). Within a typological-grammaticalisation framework, the inflectional organisation of Vilamovicean adjectives can be defined as an advanced case system.
\end{abstract}

Keywords: Germanic linguistics, endangered languages, case system, adjective, language change

\section{Introduction}

Vilamovicean is a Germanic language that is spoken in Wilamowice, a small town located in Western Galicia in Poland. Nowadays, the vernacular is understood by circa two hundred persons, although actively employed by no more than forty native speakers. All the users of the Vilamovicean idiom, who may be viewed as fully competent and proficient, were born before the Second World War. This implies that the speakers are of quite an advanced age. In addition, given their extremely reduced number and a lack of administrative commitment to teaching the tongue to the Vilamovicean youth, there is a high probability of its extinction in the near future. Most likely, in the next ten or fifteen years, the Vilamovicean language - at least, if conceived as a real social phenomenon - will cease to exist. 
In light of this imminent and, as it seems now, inevitable extinction, it is important to provide an exhaustive documentation and description of the vernacular before it is simply too late. Coming across this necessity, the author of the present paper - assisted by Tymoteusz Król ${ }^{1}-$ has been engaged in an extensive research project dedicated to the Modern Vilamovicean language since $2006^{2}$. The aim of this research was, first of all, to compose a fully representative database which would document the entire richness of the tongue. Once this database reached satisfactory dimensions and diversity, it was used as the empirical foundation of a detailed grammatical description of the language (cf. Andrason 2010a, 2010b, 2011 and 2013) and of a compendious dictionary (cf. Andrason and Król 2013).

The necessity of providing a comprehensive grammatical portrayal is not only dictated by the imminent extinction of the vernacular, but also stems from the scarcity of works devoted to the Vilamovicean language, especially of those that discuss its contemporary shape. To be exact, the only reliable grammatical descriptions of the tongue - brief and thus, in various aspects, rather superficial - were composed early in the $20^{\text {th }}$ century by Młynek (1907), Latosiński (1909) and Kleczkowski (1920 and 1921). Since that time, very little has been produced as far as the grammatical analysis of the language is concerned. The sole positions explicitly aimed at Vilamovicean and based on original empirical research are books written by Lasatowicz (1992) and Wicherkiewicz (2003). Although Lasatowicz's monograph (which aims at depicting the most important grammatical characteristics of Modern Vilamovicean) provides some new empirical evidence, its real contribution to the description of the language is limited. For example, the data offered by Lasatowicz display excessive German traces, the sources of her examples (e.g. the name and date of birth of the informants) are never indicated, and the discussion of grammatical features is restricted to the presentation of a few (one or two, at most) regular declensional and conjugational paradigms. The other publication, which is based upon an original empirical study, despite its valuable contribution to the Vilamovicean scholarship, is dedicated to the translation of the most important Vilamovicean literary text composed more than a hundred years ago by Florian Biesik. Consequently, and entirely understandably, it limits the treatment of genuine grammatical questions to a necessary minimum. In addition to these two monographs, one should mention a BA thesis written recently by Richie (2012) in which the author provides a meticulous and well-appreciated discussion of the dialectological classification of the tongue. Nevertheless, Richie does not offer new empirical evidence that could document the language, but rather re-uses the data previously collected by others.

The present paper meets the necessity of documenting the grammatical substance of Modern Vilamovicean and providing its explanation by offering a detailed description and analysis of the adjectival declensional patterns currently available in the tongue. In this manner, it will present new empirical evidence that is derived from extensive field research carried out in 2009, 2010 and 2011 in Wilamowice, in which approximately 40 informants were involved ${ }^{3}$. It should

\footnotetext{
${ }^{1}$ Tymoteusz Król - who is the only young native speaker (born in 1993) - started documenting the Vilamovicean idiom in 2004 when he was 11 years old.

2 The term "Modern Vilamovicean" makes reference to the Vilamovicean language spoken currently in the $21^{\text {st }}$ century and is employed in order to differentiate it from Classical Vilamovicean, the Vilamovicean language used before the Second World War (cf. below in this section).

${ }^{3}$ The following native speakers - ordered by the year of the birth - have been consulted: Franciszka Bilczewska fum Frycki (1913-2012), Kazimierz Grygierczyk fum Bieruniok (1913-2010), Anna Danek fum Pejtela (born 1916), Zofia Danek fum Stańću (1917-2012), Franciszek Mosler fum Mözłer (1918-2011), Helena Danek fum Kwaka (1919-2012), Jan Biba fum Tüma-Jaśki (1920-2011), Anna Sznajder fum Pejter (1920-2012), Elżbieta Mynarska fum Siöeba (born 1921), Helena Biba fum Płaćnik (born 1922), Elżbieta Babiuch fum Poükner (19232010), Anna Foks fum Prorok (1923-2011), Elżbieta Kacorzyk fum Pütrok (born 1923), Elżbieta Sznajder fum
} 
be noted that the data introduced in this article reflect the language of the most competent and proficient native speakers. Consequently, it avoids forms that arose due to imperfect language acquisition by younger speakers, especially those born after the Second World War. The article will, however, go beyond a purely descriptive task which, as mentioned, is necessary, given a limited documentation of the linguistic substance of the tongue and its imminent loss. Specifically, on the one hand, the morphological patterns of the adjectival declension in Modern Vilamovicean will be compared with the system designed by Kleczkowski $(1920,1921)$ which reflects what has been referred to as Classical Vilamovicean. At this time, the language was employed by the vast majority of the population in Wilamowice, being de facto a dominant idiom in the community ${ }^{4}$. In this manner, we will be able to determine the changes that have occurred in the adjectival case marking during the last century. On the other hand, we will discuss the adjectival case system of Modern Vilamovicean from a wider dynamic, typological or grammaticalisation perspective, situating the language on an evolutionary cline that schematises the life cycle of case organisations cross-linguistically.

To comply with these objectives, the paper will be organised in the following manner. We will begin the discussion with a purely descriptive assignment: in section 2.1 , the declensional patterns of the adjective in Classical Vilamovicean will be presented, while in section 2.2, the original empirical evidence which reflects Modern Vilamovicean usage will be introduced. In the subsequent part of the article, an explanation of the adjectival case system will be proposed. Specifically, the morphological changes between the two diachronic strata will be identified and their reasons specified (section 3.1). Thereafter, a classification will be offered of the state of the adjectival case system in Modern Vilamovicean within a dynamic, typological grammaticalisation framework (section 3.2). Finally, in section 4, major conclusions will be drawn.

\section{Adjectival case system of the Vilamovicean language - empirical evidence}

\subsection{Classical Vilamovicean}

Without doubt, the best presentation of the adjectival case system of Classical Vilamovicean can be found in the treatises written by Adam Kleczkowski in 1920 and 1921. According to

Pejter (born 1923), Anna Zejma fum Lüft (1923-2010), Elżbieta Matysiak fum Hala-Mockia (born 1924), Anna Danek fum Küpsela (born 1924), Helena Gasidło fum Biöeźniok (born 1924), Waleria Brzezina fum Cepok (born 1925), Rozalia Kowalik fum Poüermin (born 1925), Jan Formas (born 1925), Katarzyna Balcarczyk fum Karol (1925-2013), Stanisław Foks fum Lüft (born 1926), Elżbieta Formas fum Mözłer (born 1926), Katarzyna Nowak fum Tobyś (1926-2010), Rozalia Hanusz fum Linküś (1926-2009), Anna Korczyk fum Kołodźej (born 1927), Elżbieta Gąsiorek fum Anta (born 1927), Elżbieta Figwer fum Böba (born 1927), Anna Foks fum Lüft (born 1927), Kazimierz Sznajder fum Pejter (1927-2011), Ingeborg Matzner-Danek (born 1928), Helena Nowak fum Holeczkla (born 1928), Jan Balcarczyk fum Siöeba (1928-2013), Bronisława Pyka (born 1928), Helena Rozner fum Böba-Lojzkia (born 1928), Emilia Biesik fum Raczek (1929), Józef Gara fum Tołer (1929-2013), Elżbieta Merta fum Hala-Frana-Jaśkia (born 1929), Katarzyna Danek fum Pejtela (born 1929), Elżbieta Nycz fum Śleźok (1929-2007), Helena Dobroczyńska fum Osiećon (1929-2012), Elżbieta Gandor fum Baranła (born 1930), Zofia Kozieł fum Sübert (born 1930), Anna Biba fum Küćłik (1930-2009), Hilda Kasperczyk fum Ćiöe (1930-2005), Eugenia Foks fum Bröda (born 1930), Rozalia Danek fum Mjyra-Winca (born 1931), Elżbieta Nikiel fum Linküś (born 1931), Rozalia Węgrodzka fum Gadła (born 1931), Stanisław Zejma (born 1931), Stefania Kuczmierczyk fum Jonkla (born 1932), Anna Nowak fum Hala-Mockia (1932-2011), Emilia Danek fum Biöeźniok (born 1933), Kazimierz Foks fum Baranła (born 1934), Anna Kuczmierczyk fum Zelbst (born 1934), Anna Sznajder fum Pejter (born 1934), Barbara Tomanek (born 1935), Elżbieta Sznajder fum Freślik (born 1938), Stanisław Merta fum Hala-Frana-Jaśkia-Hala (1955-2011), Janusz Brzezina fum Urbon (born 1956).

${ }^{4}$ At that time, a similar vernacular was also used in Hałcnów. 
these studies, the language had three types of adjectival declension: two original declensions (i.e. a strong one and a weak one) and a mixed declension.

The strong paradigm - also labelled as a pronominal declension - was typically employed if the adjective was used without any preceding modifier, in particular, an indefinite or definite article or a demonstrative pronoun. According to Kleczkowski (1920:133), the original strong declension displayed the following set of endings (class A):

$\begin{array}{lllll} & \text { masculine } & \text { neuter } & \text { feminine } & \text { plural } \\ \text { NOM } & \text { er } & & & \\ \text { ACC } & a & y s & y & y \\ \text { DAT } & \text { um } & \text { um } & y & \text { er } \\ \end{array}$

Already at the beginning of the $20^{\text {th }}$ century, this "ideal" strong paradigm was rather unstable, and certain genuine strong endings were seldom used. In the singular, the strong declension was quite rare, often being substituted by an indefinite article and the adjective in the weak declension. This occurred regularly in the masculine and neuter dative, where um ceded its place to the weak ending $a$, and in the neuter nominative and accusative, where $y s$ was replaced by a far more frequent form with no ending. 5 . This indeclinable form was likewise - albeit significantly less seldom - used in the masculine nominative singular. As a result, the realistic - mixed (i.e. partially strong and partially weak) - paradigm had the following shape (class B):

$\begin{array}{lllll} & \text { masculine } & \text { neuter } & \text { feminine } & \text { plural } \\ \text { NOM } & e r & \varnothing & y & y \\ \text { ACC } & a & \varnothing & y & y \\ \text { DAT } & a & a & a & a\end{array}$

The "pure" weak declension was typically found if the adjective was headed by an article (either definite or indefinite) or a demonstrative pronoun. This classical paradigm offered the following endings (class C):

$\begin{array}{lllll} & \text { masculine } & \text { neuter } & \text { feminine } & \text { plural } \\ \text { NOM } & y & y & y & a \\ \text { ACC } & a & y & y & a \\ \text { DAT } & a & a & a & a\end{array}$

Two classes of adjectives provided certain peculiarities. Adjectives ending in $a$, which frequently indicated a type of material, were indeclinable in all the declensional types. Adjectives ending in $e r$, when employed in the strong and mixed declension, displayed the invariant form er in the masculine nominative singular and in the neuter nominative-accusative singular. Similarly, the form of the feminine dative singular appeared as invariable, given that the combination $e r+e r$ was regularly simplified to $e r$. All the remaining endings of this group of adjectives show the form $y n$, although er is also possible. In the weak declension, the adjectives in er could be indeclinable, displaying in all the cases the shape in $e r$, or could alternatively offer the ending $y n$ in places where the regular adjectives showed the forms in $a$.

\footnotetext{
${ }^{5}$ The original, genuinely strong form was employed in expressions such as nist guttys "nothing good" and in some fixed expressions.
} 
Although Kleczkowski (1920) exclusively mentions three classes (aforementioned in this article), certain forms provided by him enable us to refine his own conclusions. Namely, it is possible to split the first pattern (strong declension - class A) into three further subtypes which correspond to three distinct paradigms in the modern language. Firstly, after the adverb nist "nothing", the form ys seems to have been regularly preferred (cf. class 1 in section 2.2.1). Secondly, after a proper noun which is accompanied by the morpheme $s$ (the vestige of the genitive case used with proper nouns and substantives ending in er), both $y s$ and the bare form of the neuter nominative-accusative singular could be employed (cf. class 2 in section 2.2.2). Finally, in certain non-idiomatic expressions, the bare form seemed to be preferred (cf. class 3 in section 2.2.3).

In this manner, the evidence provided by Kleczkowski allows us to design a system of five declensional paradigms. Three of them are explicitly acknowledged, while two others may only be indirectly deduced.

\subsection{Modern Vilamovicean}

The Modern Vilamovicean language offers a complex system of six declensional paradigms. Although these declensional patterns are often quite similar - diverging in one, two or three endings - each one of them is typically restricted to specific contexts. In this section, a detailed description is offered of the six paradigms in which I present their formal characteristics, explain the exact range of uses and provide various instructive examples.

\subsubsection{Declensional class 1}

In accordance with the situation observed in Classical Vilamovicean, in modern times, the genuine strong declension is exclusively preserved in idioms and fixed expressions, for example: myt bywåjtum woser "with holy (lit. blessed) water", by güter cåjt "by/in a good time", myt gütum wüt "with a good word", myt fulum typa "with a full pot", cy futum moüt "to/with a full mouth", grinys kröut "a green cross", yr güter mynkjyd "(to/with) food love" and śejnys kyndła "a beautiful child". As a productive category, it appears in combination with the negative lexeme nist "nothing", for example, nist gütys "nothing good" and nist śtåhtys "nothing bad". The entire paradigm, which formally matches the strong declension described by Kleczkowski (1920; cf. class A), shows the following endings:

$\begin{array}{lllll} & \text { masculine } & \text { neuter } & \text { feminine } & \text { plural } \\ \text { NOM } & \text { er } & & & \\ \text { ACC } & a & y s & y & y \\ \text { DAT } & \text { um } & \text { um } & y & \text { er } \\ \end{array}$

It should, however, be emphasised that the above-presented paradigm is rather unrealistic, due to the fact that it fails to constitute a productive category in the living modern language. Virtually no single sequence consisting of an adjective and a noun provides all the strong forms and could be employed as an illustration of this declension. In Modern Vilamovicean, this case pattern is regularly replaced by the second, third, fourth or fifth patterns (see sections 2.2.12.2.5). 


\subsubsection{Declensional class 2}

The second declensional type is used if the adjective follows a possessive construction marked by $s$, the remnant of the genitive case, such as $S$ Jüzas "Joseph's". In these cases, the adjective quite consistently displays the endings of the type previously discussed, with one important modification. In the neuter nominative-accusative singular, two forms are always possible: one is suffix-less (this variety is also more frequent), while the other shows the strong or pronominal ending ys:

$\begin{array}{lllll} & \text { masculine } & \text { neuter } & \text { feminine } & \text { plural } \\ \text { NOM } & \text { er } & \varnothing / y s & y & y \\ \text { ACC } & a & \varnothing / y s & y & y \\ \text { DAT } \quad \text { um } & u m & \text { er } & a\end{array}$

Consider the following illustrations of this declension with the adjective duter "stupid", employed after the possessors $S$ Nüśas "Anna's" and $S$ Jüzas "Joseph's" and before the substantives klop "husband", måkja "girl”, bow "wife" and kyndyn "children":

\begin{tabular}{|c|c|c|c|c|}
\hline & masculine & feminine & neuter & plural \\
\hline TO & S Nüśas duter kłop & S Jüza dut / -ys måkja & S Jüzas duły bow & S Jüza duty kyndyn \\
\hline $\mathrm{CC}$ & S Nüśas duła kłopa & S Jüza dut / -ys måkja & S Jüzas duty bow & S Jüza duty kyndyn \\
\hline DAT & S Nüśas dułum kłop & S Jüza dutum måkja & S Jüza duter bow & S Jüza duta kyndyn \\
\hline
\end{tabular}

One should note a peculiar behaviour of the adjective jyśter "first", which in the neuter nominative-accusative singular displays the form in $a$, viz. jyst $t$, besides the indeclinable shape jyśt:

$\begin{array}{lllll} & \text { masculine } & \text { feminine } & \text { neuter } & \text { plural } \\ \text { NOM } & \text { S Nüśas jyśter klop } & \text { SJüza jyśt/-a måkja } & \text { SJüzas jyśty bow } & \text { S Jüza jyśty kyndyn } \\ \text { ACC } & \text { S Nüśas jyśta kłopa } & \text { SJüza jyśt/-a måkja } & \text { SJüzas jyśty bow } & \text { S Jüza jyśty kyndyn } \\ \text { DAT } & \text { S Nüśas jyśtum ktop } & \text { SJüza jyśtum måkja } & \text { S Jüza jyśter bow } & \text { S Jüza jyśta kyndyn }\end{array}$

\subsubsection{Declensional class 3}

The third type constitutes another modification of the original strong declension. In this class, which is rarely found in the modern language, the neuter nominative-accusative offers exclusively one shape, viz. the indeclinable or ending-less form. The remaining endings are identical to those described in the two types discussed previously.

$\begin{array}{lllll} & \text { masculine } & \text { neuter } & \text { feminine } & \text { plural } \\ \text { NOM } & \text { er } & \varnothing & y & y \\ \text { ACC } & a & \varnothing & y & y \\ \text { DAT } & \text { um } & \text { um } & \text { er } & a\end{array}$

Although seldom encountered, this type of declension may be illustrated by the following paradigm of the adjective güter "good" when it is used following the pronoun wyter "which": 


\begin{tabular}{lllll}
\multicolumn{1}{c}{ masculine } & neuter & feminine & plural \\
NOM & wyter güter klop & wyta güt måkja & wyty güty bow & wyty güty ktopa \\
ACC & wyta güta klopa & wyta güt måkja & wyty güty bow & wyty güty ktopa \\
DAT & wytum gütum ktopa & wytum gütum måkja & wyter güter bow & wyta güta ktopa
\end{tabular}

Among all the examples, the following combinations of an adjective and noun seem to be the most common: świöecer cöker "dark sugar", ruty wiöer "red material/cloth" and kołd woser "cold water". Their declension follows the rule outlined above:

$\begin{array}{llll} & \text { masculine } & \text { neuter } & \text { feminine } \\ \text { NOM } & \text { świöecer cöker } & \text { kołd woser } & \text { ruty wiöer } \\ \text { ACC } & \text { świöeca cöker } & \text { kołd woser } & \text { ruty wiöer } \\ \text { DAT } & \text { świöecum cöker } & \text { kotdum woser } & \text { ruter wiöer }\end{array}$

Adjectives that end in er, for example kośer "kosher", just like in Classical Vilamovicean, employ the suffix er in the masculine nominative singular and feminine dative singular:

$\begin{array}{llll} & \text { masculine } & \text { neuter } & \text { feminine } \\ \text { NOM } & \text { kośer } & \text { kośer } & \text { kośery } \\ \text { ACC } & \text { kośera } & \text { kośer } & \text { kośery } \\ \text { DAT } & \text { kośerum } & \text { kośerum } & \text { kośer }\end{array}$

The distinction between the three paradigms presented thus far is related to the shape of the neuter nominative-accusative form in the singular. While class 1 regularly employs the form in ys (gütys), class 3 typically uses the bare form (güt). Class 2, in turn, permits two options, namely both the form in ys and ending-less. The three classes are also confined to three different environments: (i) forms of class 1 are residual, appearing in fixed idiomatic expressions and in combination with the adverb nist; (ii) class 2 is regularly used with the substantives marked by the possessor ending $s$ (typically proper nouns or nouns ending in er denoting professions), and (iii) class 3 is found with a few adjectives and following the interrogative pronoun wyter.

\subsubsection{Declensional class 4}

Another declensional type appears in constructions where the adjective, headed by an indefinite article, is used in apposition to the preceding indefinite noun: å måkja å gütys "a good girl" (lit. "a girl, a good [one]"). Such formations are quite frequent in the modern language and may appear in all the genders, numbers and cases: å kyndta å klinys "a small child", kłopa güty "good men", or ån rynk ån śejna "a beautiful market". The distinctive feature is the ys ending in the neuter nominative-accusative singular and the $a$ form of the masculine, neuter and feminine dative singular. It should also be observed that the dative masculine and neuter singular optionally display an extra $m$ so that two forms are possible: güta or gütam. The entire pattern may be posited as follows:

$\begin{array}{lllll} & \text { masculine } & \text { neuter } & \text { feminine } & \text { plural } \\ \text { NOM } & \text { er } & y s & y & y \\ \text { ACC } & a & y s & y & y \\ \text { DAT } \quad \text { a } / \text { am } & \text { a /am } & a & a\end{array}$




$\begin{array}{lllll} & \text { masculine } & \text { neuter } & \text { feminine } & \text { plural } \\ \text { NOM } & \text { å kłop å güter } & \text { å måkja å gütys } & \text { å bow å güty } & \text { kłopa güty } \\ \text { ACC } & \text { ån ktopa ån güta } & \text { a måkja å gütys } & \text { å bow å güty } & \text { kłopa güty } \\ \text { DAT } & \text { åm kłopa åm güta /_am } & \text { åm måkja åm güta /-am } & \text { år bow år güta } & \text { ktopa güta }\end{array}$

Although adjectives ending in $a$ (such as åjzera "iron, strong", stanera "stone", or stytera "steal") are usually indeclinable, showing the form in $a$ in all the cases, numbers and genders, they may also offer certain peculiarities in this declensional class. To be exact, the masculine accusative singular and dative plural possess alternative forms in an (for instance, åjzeran) besides the regular shape in $a$ (ajzera). To illustrate this, one can compare two uses of the adjective gytdyra "golden" in the masculine accusative singular. If the adjective follows the indefinite article and modifies a noun that follows, it offers the indeclinable shape $a$ : Yh ho an gytdyra gyzunda "I have a golden health" (cf. declension class 5 in section 2.2.5). However, when the adjective appears in the syntactic structure typical to the fourth declensional pattern, it may display the ending $n$ : Yh ho ån gyzunda ån gytderan "I have a golden health".

\subsubsection{Declensional class 5}

The fifth declension is a typical mixed pattern that already existed in Classical Vilamovicean (cf. class B in section 2.1). It usually appears if the adjective is preceded by an indefinite article and shows the following endings:

$\begin{array}{lllll} & \text { masculine } & \text { neuter } & \text { feminine } & \text { plural } \\ \text { NOM } & \text { er } & \varnothing & y & y \\ \text { ACC } & a & \varnothing & y & y \\ \text { DAT } & a & a & a & a\end{array}$

To illustrate this declensional pattern, the expressions å güter kłop "a good man", å güt måkja "a good girl" and å güty bow "a good woman" will be employed:

\begin{tabular}{|c|c|c|c|c|}
\hline & masculine & neuter & feminine & plural \\
\hline NOM & å güter ktop & å güt måkja & å güty bow & güty kłopa \\
\hline ACC & ån güta kłopa & å güt måkja & å güty bow & güty kłopa \\
\hline DAT & åm güta kłopa & åm güta måkja & år güta bow & güta kłopa \\
\hline
\end{tabular}

The same pattern may be found if the adjective is headed by the pronoun ka "no, no one, any" or a possessive pronoun, such as måj "my", daj "your", etc. However, in these cases, the feminine dative singular shows an alternative form, i.e. $y$. In this manner, the feminine adjectives in the singular may become invariant, displaying in all the cases the same shape $y$ :

\begin{tabular}{|c|c|c|c|c|}
\hline & masculine & neuter & feminine & plural \\
\hline NOM & kå güter kłop & kå güt måkja & kå güty bow & kå güty kłopa \\
\hline $\mathrm{ACC}$ & kån güta kłopa & kå güt måkja & kå güty bow & kå güty klopa \\
\hline \multirow[t]{2}{*}{ DAT } & kåm güta ktopa & kåm güta måkja & kår güta / y bow & kån güta kłopa \\
\hline & masculine & neuter & feminine & plural \\
\hline NOM & måj güter kłop & måj güt måkja & måj güty bow & måj güty kłopa \\
\hline$\Delta C$ & men güta kłopa & måj güt måkja & måj güty bow & måj güty ktopa \\
\hline DAT & mem güta klopa & mem güta måkja & mer güta /-y bow & men güta kłopa \\
\hline
\end{tabular}


The use of an adjective with a pronoun (a) zyter "such (a)" follows this pattern, also offering the possibility of having the form $y$ in the masculine nominative singular:

\begin{tabular}{lllll}
\multicolumn{2}{c}{ masculine } & neuter & feminine & plural \\
NOM & å zyter gutter/-y klop & å zyta güt måkja & a zyty güty bow & zyty güty büwa \\
ACC & ån zyta güta ktopa & å zyta güt måkja & å zyty güty bow & zyty güty büwa \\
DAT & åm zyta güta ktopa & åm zyta güta måkja & år zyta güta /-y bow & zyta güta büwa
\end{tabular}

Again, adjectives ending in er (such as kośer) slightly diverge from the norm and show an indeclinable basic form er in the masculine nominative singular. Additionally, feminine nouns may offer the invariant form er in all the cases in the singular.

$\begin{array}{lllll} & \text { masculine } & \text { neuter } & \text { feminine } & \text { plural } \\ \text { NOM } & \text { kośer } & \text { kośer } & \text { kośery / kośer } & \text { kośery } \\ \text { ACC } & \text { kośera } & \text { kośer } & \text { kośery / kośer } & \text { kośery } \\ \text { DAT } & \text { kośera } & \text { kośera } & \text { kośera / kośer } & \text { kośera }\end{array}$

\subsubsection{Declensional class 6}

The last pattern corresponds to a typical weak declension, which also existed in Classical Vilamovicean (cf. class $\mathrm{C}$ in section 2.1). The modern endings mirror the system available at the beginning of the $20^{\text {th }}$ century with two important modifications. Firstly, the feminine dative singular, besides offering the regular ending $a$ (e.g. güta), additionally possesses an alternative shape $y$ (e.g. güty). Accordingly, feminine adjectives can show one form (y) in all the cases in the singular (e.g. güty). In addition, the nominative-accusative plural may adopt the ending $y$ instead of the regular $a$. The entire weak paradigm in Modern Vilamovicean is as follows:

$\begin{array}{lllll} & \text { masculine } & \text { neuter } & \text { feminine } & \text { plural } \\ \text { NOM } & y & y & y & a / y \\ \text { ACC } & a & y & y & a / y \\ \text { DAT } & a & a & a / y & a\end{array}$

The weak declension most commonly appears if the adjective is headed by a demonstrative pronoun (dar, dos and $d i)$ and by a definite article (der, $d y$ and $s)$ :

\begin{tabular}{|c|c|c|c|c|}
\hline & masculine & neuter & feminine & plural \\
\hline NOM & dar güty klop & dos güty måkja & di güty bow & di güta / -y kłopa \\
\hline $\mathrm{ACC}$ & dan güta kłopa & dos güty måkja & di güty bow & di güta /-y kłopa \\
\hline \multirow[t]{2}{*}{ DAT } & dam güta kłopa & dam güta måkja & dar güta / -y bow & dan güta kłopa \\
\hline & masculine & neuter & feminine & plural \\
\hline NOM & der güty kłop & $s$ güty måkja & dy güty bow & dy güta /-y klopa \\
\hline ACC & dan güta kłopa & $s$ güty måkja & dy güty bow & dy güta /-y kłopa \\
\hline DAT & ym güta klopa & ym güta måkja & yr güta / -y bow & yn güta ktopa \\
\hline
\end{tabular}

The adjectives ending in er mainly follow the above-presented paradigm, although "irregular" forms may sometimes be found. For instance, the indeclinable shape er (koser) appears in the feminine dative and neuter nominative-accusative singular. It also seems that the plural morpheme $a$ (kośera) is more frequent in the group of adjectives ending in er. 


\subsubsection{Summarising the evidence}

In the previous sections, six different declensional paradigms have been introduced. Instead of constituting an "accidental" organisation of chaotic patterns, all the classes may be viewed as connected. In other words, if one considers the original strong pronominal inflection being one declensional "pole", with the weak inflection being another one, it is possible to arrange all the discussed classes into a continuum of paradigms that are closer to one of the two mentioned extremes. Therefore, the situation in Modern Vilamovicean would correspond to a gamut of forms that range from "stronger" ones to "weaker" ones and thus the six paradigms show an increase or decrease in weak and strong prototypicality. Accordingly, class 1 is the optimal strong pronominal declension, while class 6 is the optimal weak paradigm. In between, there are four mixed classes in which the decrease of strong characteristics is compensated for by the increase in weak traits 6 .

\begin{tabular}{|c|c|c|c|c|c|c|c|c|c|}
\hline & MS & NT & FM & PL & & MS & NT & FM & PL \\
\hline NOM & er & $y s$ & $y$ & $y$ & 4 & er & $y s$ & $y$ & $y$ \\
\hline $\mathrm{ACC}$ & $a$ & $y s$ & $y$ & $y$ & & $a / a n^{7}$ & $y s$ & $y$ & $y$ \\
\hline DAT & $u m$ & um & er & a & & a/am & a/am & $a$ & alan \\
\hline $\mathrm{NOM}$ & er & $\varnothing / y_{s}$ & $y$ & $y$ & 5 & $e r / y^{8}$ & $\varnothing$ & $y^{9}$ & $y$ \\
\hline ACC & $a$ & $\varnothing / y s$ & $y$ & $y$ & & $a$ & $\varnothing$ & $y$ & $y$ \\
\hline DAT & $u m$ & um & er & $a$ & & $a$ & $\widetilde{a}$ & $a / y^{10}$ & $a$ \\
\hline NOM & er & $\varnothing$ & $y$ & $y$ & 6 & $y$ & $y$ & $y$ & aly \\
\hline ACC & $a$ & $\varnothing$ & $y$ & $y$ & & $a$ & $y$ & $y$ & $a / y$ \\
\hline DAT & um & um & er & $a$ & & $a$ & $a$ & a/y & $a$ \\
\hline
\end{tabular}

The systematic weight of the six patterns is not identical. Recall that class 1 is highly uncommon and almost entirely unproductive - its only productive context is the use of the neuter form after the negative word nist. Class 2 is productive but restricted to one context - it appears after a noun in the possessive-genitive expression in $s$. Class 3 is infrequent, being confined to a few adjectives and, apart from them, to one productive syntactic environment, i.e. after the pronoun wyter. On the contrary, classes 4, 5 and 6 are frequent and productive. Class 4 , however, typically appears in one syntactic milieu, while the remaining two subtypes are found in a greater variety of contexts.

It should be noted that in the most common and fully productive paradigms (classes 4, 5 and 6), there are in fact only two forms for each gender: a nominative vs. oblique in the masculine singular $(e r-a)$, and nominative-accusative vs. dative elsewhere (neuter: $y s-a ; \varnothing-a$ and $y-$ $a$; feminine: $y-e r$ and $y-a$; and plural $y-a$ ). Likewise, in rarely-used classes 1, 2 and 3, the feminine, neuter and plural adjectives take only two forms. It is exclusively the masculine of the first three classes that has three distinct forms. Moreover, in classes 4 and 5, there are only

\footnotetext{
${ }^{6}$ The first three classes are strong types. However, only class 1 shows typical pronominal ending $s$ in the neuter nominative-accusative singular. Classes 2 and 3 admit bare forms, which are less representative to pronouns. In the set of pronouns, such zero-endings are much less frequent than the forms in $s$. In their most characteristic usage, they are found in the group of possessive pronouns when a given pronominal lexeme is employed attributively, i.e. as an adjectival modifier.

7 The $n$ ending is typical to adjectives in $a$.

8 The form in $y$ is possible with the pronoun a zyter.

9 Feminine nouns ending in er may use the form er in the three cases in the singular.

${ }^{10}$ The form in $y$ is possible with possessive pronouns and the expression år zyta.
} 
four different endings (class 4: er, $a, y s$ and $y$; class 5: er, $a, \varnothing$ and $y$ - the ending er only in the masculine nominative singular) and in class 6 , there are, uniquely, two endings ( $y$ and $a$ ). Furthermore, in class 4 and, especially, class 5 there is a tendency to generalise one form in all the cases in the feminine singular and in the plural and thus to lose entirely a morphological distinction of the cases.

\section{Discussion}

The evidence introduced in the previous part of the article demonstrates that, although the essence of the adjective declensions has remained the same over one hundred years, certain adjustments may be observed. In the following section, I will provide a detailed account of the changes and propose an explanation for them, specifying possible sources of these novel forms. Subsequently, a typological classification of the adjectival case system will be offered and its place in the entire declensional organisation of Modern Vilamovicean will then be posited (section 3.2).

\subsection{Developments in the Vilamovicean adjectival case system}

\subsubsection{From Classical Vilamovicean to Modern Vilamovicean - review of changes}

As previously mentioned, generally speaking, Modern Vilamovicean has preserved the declensional system of the classical language. This is most evident in classes 1,2 and 3 which correspond perfectly to type A (with its subclasses) as established by Kleczkowski (1920). The empirical study dedicated to Modern Vilamovicean has enabled us to determine systematic dissimilarities, be they morphological or contextual, between these three classes. Importantly, in this way, the description offered by Kleczkowski (1920) has been improved.

With respect to the differences between Classical and Modern Vilamovicean, an attentive reader would immediately note that in contrast to the situation depicted by Kleczkowski (1920), which reflects the period before the Second World War, the modern language possesses an additional declensional paradigm, i.e. class 4 . However, it is very likely that this declensional type, which is highly common in Modern Vilamovicean but entirely omitted by Kleczkowski (1920), did exist in the classical language, given that the oldest speakers are fully familiar with it. One should also note that the syntactic environment prototypical to class 4 is quite common in the Germanic family (cf. German ein guter or English a good one). On the other hand, the question of whether the modern endings are identical to those that were in use at the beginning of the $20^{\text {th }}$ century cannot be answered satisfactorily due to the lack of direct historical data since, as explained, the classical publications do not mention this class.

The real changes between the Classical and Modern adjectival case systems concern new endings in classes 5 and 6 , as well as alternative forms available in the previously mentioned class 4. Although classes 5 and 6 are similar to the paradigms mentioned by Kleczkowski (1920), several adjustments can be observed. Firstly, the feminine dative singular (originally in $e r$ ) has developed a new form in $y$ (classes 5 and 6). Secondly, the nominative-accusative plural (initially in $a$ ) has produced a by-form in $y$ (class 6). Thirdly, in one context, the masculine nominative singular in $e r$ has acquired an alternative shape in $y$ (class 5). Likewise, with respect to class 4 , certain novel formations can be postulated. Here, a direct comparison with the classical language is unfortunately impossible, given that this type was omitted by Kleczkowski (1920). However, by contrasting the prototypical endings with the less prototypical ones, it is 
possible to hypothesise that determined morphological modification might have occurred. The prototypical forms of class 4 are the forms that a) appear in most environments; b) are shared by the majority of our informants, and c) are analogical to respective forms found in another paradigm where the adjective is headed by the indefinite article $\stackrel{a}{a}$, i.e. class 6 . In this manner, two changes can be identified: firstly, the masculine-neuter dative singular acquired an innovative form in $m$, and secondly, the masculine-neuter singular and dative plural both received a new ending: $n$.

Consequently, the evidence provided in section 2.2 enables us to detect a relatively important number of adjustments. As will be explained, some modifications have their roots in the transfer of endings from one paradigm to another, while others stem from the influence exerted by the case system of nouns, pronouns and articles. In order to properly understand this relation between adjectival, nominal and pronominal paradigms, and thus to comprehend the origin of the morphological changes affecting the adjectival declension, the major properties of the case systems of nouns, pronouns and articles must be explained.

\subsubsection{Case systems of nouns, pronouns and articles in Modern Vilamovicean}

In general terms, the case system in Modern Vilamovicean is in a state of gradual decay. However, the degree of morphological decay of case endings is distinct in nouns and pronouns. First of all, it must be noted that the genitive is nowadays entirely lost as a productive category, being confined to proper nouns (and certain substantives in er denoting professions) as an indicator of a possessor: $S$ Jüzas "Joseph's". The functions that were once carried out by the genitive case marking are currently expressed by prepositions or by pronominal constructions ${ }^{11}$. In fact, in most cases, the relations between the elements of a phrase, although sometimes still marked by a case ending, are principally conveyed by word order or prepositions. This is especially true for nouns.

As far as the nominal case system is concerned, the endings merged to the state where uniquely two shapes, either $a$ or $n$, are available. Most commonly, substantives display two forms: one in the singular (no ending) and another in the plural ( $a$ or $n ;{ }^{12}$ no ending is also possible and especially frequent with neuter nouns $)^{13}$. If the nominative plural is ending-less, the dative is typically marked by $a$ or $n$. Exceptionally, the accusative and dative singular are marked by an ending (if so, with no exception, by the vowel $a$ ). This never occurs in neuter and feminine substantives and is restricted to a few masculine substantives. Thus, nouns have almost lost the case endings and the morphological marking is usually preserved in order to indicate the plural. It should also be observed that nowadays the ending $a$ is particularly intrusive in the nominal system, spreading to various forms where, previously, the morpheme $n$ was regularly used. Additionally, as already mentioned, in cases where the accusative and dative cases are morphologically marked, the ending $a$ is invariably employed (for a more detailed description of the nominal case system, see Andrason forthcoming (a)).

The declension of pronouns is more conservative and offers a greater variety of endings such as $a, n, r, m, s$ or $y$. The group of personal pronouns clearly distinguishes all the three cases in all the genders and numbers. However, the remaining subtypes (demonstrative, indefinite,

\footnotetext{
${ }^{11}$ The loss of the genitive but preservation of the dative (or the merger of the two cases under the dative form) is common in the Germanic family (cf. for instance, Faroese and Pennsylvanian German (Blake 2001:174)).

${ }^{12}$ The distribution of these two endings most frequently depends on phonetic features of the noun.

${ }^{13}$ The plural may also be marked by an umlaut.
} 
relative, interrogative and possessive pronouns) are less straightforward in this morphological differentiation. To be precise, the three cases tend to be morphologically distinct only in the masculine singular, while in the feminine and neuter singular, as well as in the plural of all genders, the shapes of the nominative and accusative are identical. Thus, in the feminine singular, neuter singular and the plural of all genders, two morphological cases exist: nominative-accusative and dative. In the pronominal system, two forms of the endings may be viewed as invasive: $y$ and, especially, $a$. The competition of these two forms can be observed in the plural, where some pronouns prefer the ending $y$, others opt for $a$, and yet others employ both forms ${ }^{14}$. Although the core of the pronominal case system remains unaltered since the beginning of the $20^{\text {th }}$ century, certain modifications have also occurred in recent times. As a result of the changes, most commonly, the simplest (i.e. morphologically least complex) and most frequent forms have analogically been extended to other cases so that certain pronouns may nowadays be uninflected (for example, the form måj "my" may be used in all the cases, genders and numbers). In addition, multiple by-forms appear due to the confusion of case endings (where one form is "borrowed" from another case) or due to an innovation (where a new ending is shaped by compounding morphemes which are typical to more than one original form; for a comprehensive presentation of the pronominal system of Modern Vilamovicean, see Andrason forthcoming (b)).

Finally, one should also bear in mind the declensional pattern of the articles. The definite article is, in fact, an unstressed demonstrative pronoun and hence shows the traits characteristic to pronouns: three-case distinction in the masculine singular and two-case distinction (nominative-accusative vs. dative) in the feminine and neuter singular, and in the plural of all genders. The indefinite article, which possesses only singular forms, behaves in an analogical manner in that the three-case distinction exists exclusively in the masculine.

\subsubsection{Explanation of changes in the adjectival declension of Modern Vilamovicean}

Having explained the main properties of the declensional systems of nouns, pronouns and articles, let us return to the analysis of the changes occurring in the case systems of adjectives. We have previously detected four principal morphological modifications in the paradigms: new forms in am (masculine-neuter dative singular) and in an (masculine accusative singular and dative plural), the use of $y$ instead of $a$ (feminine dative singular and nominative-accusative plural) and er (masculine nominative singular). What follows is a more detailed explanation of these changes.

Class 4 displays the ending am which appears in the masculine and neuter dative singular instead of the more regular $a$. This novel formation may be contamination of the original $u m$ by the vowel of the "weaker" paradigms (classes 5 and 6) or it could correspond to an augmentation of the already levelled $a$ by the consonant $m$. The latter scenario seems far more probable given the fact that the forms in $a$ clearly predominate in this class and may be viewed as more original. In this respect, one should note that a related paradigm (class 5), where the adjective is likewise headed by the indefinite article, regularly displays the ending $a$ in such cases. The consonant $m$ itself could be borrowed from paradigms 1,2 and 3, or could be induced by an influence from the dative form of pronouns and articles, which invariably display shapes in $m$ : personal pronoun ejm, jum, -um /-m "to him, it"; demonstrative pronouns dam "to this" and jem "to that"; indefinite pronouns kåm "to no one" and idum "to every"; interrogative

\footnotetext{
${ }^{14}$ In the dative plural, the ending $a$ (or $n$ ) is a rule while $y$ is unavailable here.
} 
pronoun wam "to whom?" and possessive pronouns such as mem "to me"; definite article ym, $m$ "to the" and indefinite article a $\mathrm{a} m$ "to a". The interference of the indefinite article is especially probable since a sequence such as åm kłopa åm güta could easily evolve into åm kłopa åm gütam through contamination by the two preceding $m$ forms of the article.

The other innovative consonantal form, i.e. ending an, is also found in class 4 . It appears in the masculine-accusative singular and dative plural of all genders, being limited, however, to the adjectives in $a$. This form, which most probably corresponds to an extension of the original ending $a$ by an extra $n$, may (like the previously analysed ending $a m$ ) be an intruder from the declension of pronouns and articles. As far as the masculine-accusative singular is concerned, the following pronominal entities may have stimulated the use of the consonant $n$ as the case ending of the adjective: personal pronoun ejn "him"; demonstrative pronouns dan "this" and jen "that"; indefinite pronoun kån "no one"; interrogative pronoun wan "whom"; and possessive pronouns men "my", den "your", zen "his", ynzyn "our" and ojyn "your [pl.]". The shape of the accusative case of the indefinite article (an) may also play a prominent role in this process: ån gyzunda ån gytdera > ån gyzunda ån gytderan. Thus, the mechanisms of this change would be identical to the case of the ending am.

A similar scenario can be posited for the consonant $n$ in the dative plural which could have been induced by the following pronominal forms: personal pronouns ejn, (j)yn, -n "them"; demonstrative pronouns like dan "these" and jen "those"; indefinite pronoun kån "no one" and possessive pronouns men "my", den "your", zen "his", ynzyn "our" and ojyn "your [pl.]". The unstressed form of the dative plural of the definite article $(-n)$ may likewise participate in this development. The incorporation of $n$ into the case ending of the dative plural $a$ and thus the formation of the ending an may also have been stimulated by the fact that the dative plural of various nouns ends in $n$. On the other hand, in contrast to the changes discussed above, the indefinite article could not have played any role in this evolution since no indefinite plural article exists in the language. Thus, gyzunda gytderan could not have arisen by a contamination by the $n$ form of the article. This fact also suggests that the pronominal forms may have actively participated in the generalisation of the endings $m$ and $n$ in the singular, as discussed above.

Another change appears in classes 5 and 6 where the classical feminine dative singular in $a$ can be replaced by the vowel $y$. This modification most likely corresponds to a paradigm-internal development whereby the nominative-accusative forms in $y$ exert a regulatory influence on the shape of the dative $a$, adjusting it to $y$. Here, the influence of the case systems of pronouns, articles or nouns is impossible, since no pronouns, articles or nouns offer the case ending in $y$ in the feminine dative singular. In fact, pronouns and articles almost invariably show the ending $r$.

The levelling process may also be observed in the use of the ending $y$ in the nominativeaccusative plural in class 6 instead of the etymologically correct shape in $a$. Here, one principally deals with an analogical extension of the same forms in $y$ from classes 1-5 to the only declensional type where $a$ was employed. In this manner, the weak declension, the only one that originally possessed a distinct set of endings in the plural, has been adjusted to the dominant plural case forms and, consequently, all the paradigms offer identical endings. However, this change may also have been prompted by a paradigm-internal levelling: observe that the ending $y$ clearly predominates in the nominative-accusative in the singular of class 6 , where the masculine nominative exclusively has the shape in $a$, while all the remaining cases display the form in $y$. 
In addition, a new form in $y$ sometimes occurs in the masculine nominative singular in class 5, especially after the pronoun a zyter, instead of er. It seems that this form has arisen through an influence from class 6 where the weak ending $y$ is regular.

One should also mention some changes that led to the creation of classes 4 and 5 . Both classes, if only regular endings are envisaged, already existed before the Second World War (cf. Kleczkowski 1920). As far as the singular forms are involved, these sets of endings reflect a combination of weak and strong features: strong endings are prominent in the nominative and accusative, while the weak ones dominate in the dative. In order to visualise this mixing, in the following figure the classical forms of classes 4 and 5 are provided. The etymologically strong forms are marked in bold while weak endings are left unmarked. Furthermore, endings placed in brackets correspond to forms that are historically ${ }^{15}$ identical in both declensions and could be both strong and weak. These mixed declensions are not a Vilamovicean innovation but constitute a typical German feature (cf. the mixed declension in German which appears if the adjective is headed by an indefinite article or possessive pronoun).

\begin{tabular}{lllllll} 
& Class 4 & \multicolumn{5}{c}{ Class 5} \\
NOM & $\boldsymbol{e r}$ & $\boldsymbol{y s}$ & {$[y]$} & $\boldsymbol{e r}$ & $\varnothing$ & {$[y]$} \\
ACC & {$[a]$} & $\boldsymbol{y s}$ & {$[y]$} & {$[a]$} & $\varnothing$ & {$[y]$} \\
DAT & $a$ & $a$ & $a$ & $a$ & $a$ & $a$
\end{tabular}

\subsection{The state of the adjectival declension in Modern Vilamovicean}

It seems that the declensional organisation of adjectives in Modern Vilamovicean drives towards a two-case system - typologically, the most advanced stage of an evolution of case systems, viewed by the grammaticalisation theory and diachronic typology as located immediately before the final disappearance of the morphological case marking.

In "old" or diachronically advanced declensional systems (i.e. in organisations which have greatly progressed on the grammaticalisation cycle of cases), morphological case marking is profoundly eroded, failing to provide a sufficiently explicit indication of the roles of the components of a phrase, and the use of prepositions or other, more elaborated constructions becomes necessary. As the endings converge and distinctions between individual cases disappear, cases merge into extremely broad categories and, before disappearing entirely, in a quite regular manner, deliver systems with a two-case distinction. Most typically, the nominative is contrasted with the oblique (see, for example, early Romance languages in the Middle Ages). Additionally, in highly developed case systems, there is a constant exchange of forms between paradigms: one paradigm can be levelled by analogy with another, or a distinction made in one paradigm can be transferred to another. Usually, the morphological case system tends to disappear first on substantives, being retained for a longer time in pronouns. As a result, in a given language a case system may persist at one of its levels (pronouns) while it has been lost in others (nouns; cf. Dahl 2001; Croft 2003:33-34, 40, 245, 252, 256; Hopper and Traugott 2003:110-111; Blake 2001:156, 168-169, 170, 175, 176-179; Primus 2011:307-309).

Modern Vilamovicean shows all the characteristics of a highly advanced case system as outlined above. To be exact, various changes have meant that the case system is quite dysfunctional, being frequently incapable of an adequate differentiation between cases. As the

\footnotetext{
15 This etymological similarity concerns the history of the Vilamovicean language. Of course, these endings had distinct Proto-Germanic ancestors.
} 
same ending may be used to mark different cases, the morphological case distinction is rather imprecise. It is the word order, prepositions or other circumlocutions that specify the role of the components of the phrase. The loss of the morphological case system is almost accomplished in nouns, while pronouns - especially the set of personal pronouns and a vast majority of other pronouns in the masculine singular - still resist. However, the tendency towards a two-case organisation, which, as mentioned, is characteristic of diachronically advanced case organisations, is clearly detectable in pronouns, being a rule in demonstrative, indefinite and possessive pronouns in the neuter and feminine singular, and in the plural.

Adjectives can be located in-between these two poles. To be exact, in Modern Vilamovicean, one observes a progression in the merging and/or syncretism of adjectival cases, principally driven by analogical levelling. The imposition of the two-case marking is evident, and in some cases there are traces of a total regularisation of the ending in all the cases. In this manner, the morphological case marking on adjectives, which was already relatively dysfunctional at the beginning of the $20^{\text {th }}$ century, has become even more inefficient. In Modern Vilamovicean, in order to clarify the function of an adjectival entity, the language must employ alternative mechanisms, more commonly word order or prepositions. The presence of an indefinite or definite article also significantly contributes to this clarification, given that these forms preserve the case marking better than the adjectives.

Additionally, as in a typical advanced case system, a constant transfer of endings may be observed. These modifications stem from three types of analogical changes: the internal paradigm-levelling (where the paradigm extends one form to other cases); levelling between paradigms (a form which spreads from one set of paradigms to another), and an influence from other declensional types, especially from the more "active" system of pronouns and articles (where pronominal forms are generalised on adjectives).

Although the Vilamovicean adjectives comply with the properties of an "old" case system, the interaction between different paradigms and declensional subsystems triggers certain changes that seem to work against the loss of the morphological case system. To put it differently, a type of prophylaxis against the case-dysfunctionality may be detected. As such, the innovation of the endings $m$ and $n$ may be viewed as an attempt to differentiate certain cases from others. Additionally, it should be noted that while the morpheme $a$ is the most aggressive ending in the nominal system, in the adjectival declension, the vowel $y$ (also employed in substantives) is most typically used in innovations.

\section{Conclusion}

In accordance with the objectives of the article, I have offered a detailed description and analysis of the adjectival case system in Modern Vilamovicean: the language possesses six declensional patterns, the morphological traits of which enable us to arrange them into a continuum that connects two poles, namely strong declension (classes 1 [typically pronominal], 2 and 3 ["less" pronominal]) and weak declension (class 6). Intermediate or mixed classes (4 and 5) are located between these two "extremes" according to increasing or decreasing strong and weak properties. Each class is restricted to a distinct environment. In this system of six classes, only three types are fully productive (classes 4, 5 and 6), while the others (classes 1, 2 and 3) are either residual or very seldom met. 
The detailed description of the adjectival declension in Modern Vilamovicean has also allowed us to detect certain developments in comparison with the classical language. These changes were shown to follow the main tendencies in the evolution of the case system of Modern Vilamovicean, which is in the process of a gradual decay. The adjectival declension suffers a decay process of merging and syncretism of cases driving towards a two-case marking: nominative vs. accusative-dative in the masculine singular and nominative-accusative vs. dative elsewhere. A further decay may likewise be observed as the case distinction is sometimes entirely eliminated. On the other hand, the influence from the other declensional subsystems of the language (i.e. from pronouns and articles) has, in some instances, an opposite prophylactic effect: some adjectives have developed new, more effective case markers which partially prevent or, at least, slow down the decay of the adjectival case marking.

On the whole, the case system of adjectives can be viewed as more effective than the nominal system (where almost no case distinctions are preserved) but less functional than the pronominal one (where two or even three case distinctions are regularly made). From a dynamic typological perspective, it is an exemplary advanced case organisation.

\section{References}

Andrason, A. 2010a. Vilamovicean verbal system - Do the Preterite and the Perfect mean the same? Linguistica Copernicana 3: 271-285.

Andrason, A. 2010b. Expressions of futurity in the Vilamovicean language. Stellenbosch Papers in Linguistics PLUS 40: 1-11.

Andrason, A. 2011. Vilamovicean passive. Linguistica Copernicana 5: 221-242.

Andrason, A. 2013. The semantics of the Vilamovicean verbal system - Part 1 (empirical study). Studia Linguisticae Universitatis Iagellonicae Cracoviensis 130: 7-39.

Andrason, A. (forthcoming (a)). The Vilamovicean case system of nouns - From the $20^{\text {th }}$ to the $21^{\text {st }}$ century.

Andrason, A. (forthcoming (b)). Description of the pronominal system of Modern Vilamovicean.

Andrason, A. and T. Król. 2013. Materials for the Vilamovicean dictionary - the letter Z. Annales Neophilologiarum 6.

Blake, B. 2001. Case. Cambridge: Cambridge University Press.

Croft, W. 2003. Typology and universals. Cambridge: Cambridge University Press.

Dahl, Ö. 2001. Grammaticalization and the life cycles of constructions. RASK - Internationalt tidsskrift for sprog og kommunikation 14: 91-134.

Hopper, P. and E. Traugott. 2003. Grammaticalization. Cambridge: Cambridge University Press. 
Kleczkowski, A. 1920. Dialekt Wilamowic w zachodniej Galicji. Fonetyka i fleksja. Kraków: Polska Akademia Umiejętności.

Kleczkowski, A. 1921. Dialekt Wilamowic w zachodniej Galicji. Składnia i szyk wyrazów. Poznań: Polska Akademia Umiejętności.

Lasatowicz, M. 1992. Die deutsche Mundart von Wilamowice zwischen 1920 und 1987. Opole: Wyższa Szkoła Pedagogiczna.

Latosiński, J. 1909 [1990]. Monografia Miasteczka Wilamowic. Na podstawie źródet autentycznych. Kraków: Drukarnia Literacka pod zarządem L.K. Górskiego.

Młynek, L. 1907. Narzecze wilamowickie. Tarnów: J. Pisz.

Primus, B. 2011. Case-marking typology. In J.J. Song (ed.) The Oxford handbook of linguistic typology. Oxford: Oxford University Press. pp. 303-321.

Ritchie, C. 2012. Some considerations on the origins of Wymysorys. Unpublished BA thesis, University of Sydney.

Wicherkiewicz, T. 2003. The making of a language. Berlin: Mouton de Gruyter. 